\title{
PENGARUH STRATEGI POW+TREE TERHADAP KEMAMPUAN MENULIS PARAGRAF
}

\author{
Hidayatul Dina \\ Hidhayatuldina116@gmail.com \\ Universitas Riau, Pekanbaru, Indonesia
}

\begin{abstract}
POW+TREE Strategy helps students write and develop the ideas easily. However, not all of students were able to write the text types. The objective of this research to find out whether there is significant effect of POW+TREE Strategy towards students' writing ability of the students at SDN 169 Pekanbaru. This research was experimental research which had two classes experimental class and control class. This research focused on writing text paragraph. The researcher applied the POW+TREE Strategy in experimental class. While, in control class the researcher did not apply the strategy. Further, the researchers gave two tests for the students, pre and post test. Then, the researchers gave pretest before giving the treatment. And then, the researchers gave post-test after applied the treatment in experimental class. The result of students' score in control class were, the researchers got mean score of pre-test was 46.17. While, in post-test, the reseracher got mean score was 60.67. However, the researcher got students' mean score in experimental class was 49.5. After the researchers applied the POW+TREE Strategy, the mean score of students become 65.50. Thus, there was increase of students score after using the strategy. Based on the researchers' analysis by using SPSS 22.0 program by using Kolmogorov-Smirnov, the researchers got significant test was 0.05. it was same with the standard significant. In brief, there was significant effect of POW+TREE Strategy towards students' writing ability of the students at SDN 169 Pekanbaru.
\end{abstract}

Keywords: writing, pow+tree strategy

\begin{abstract}
ABSTRAK
Tujuan dari penelitian ini untuk mengetahui apakah ada pengaruh yang signifikan dari Strategi $P O W+T R E E$ terhadap kemampuan menulis siswa di SDN 169 Pekanbaru.Penelitian ini adalah penelitian eksperimen yang memiliki dua kelas yaitu kelas eksperimen dan kelas kontrol yang mana strategi $P O W+T R E E$ diterapkan pada kelas eksperimen. Adapun instrumen dalam penelitian ini adalah berbentuk test, yaitu tes awal yang bertujuan untuk mengetahui kemampuan dasar siswa dan test akhir untuk mengetahui kemampuan siswa setelah diterapkannya $P O W+T R E E$. Hasil skorpretest siswa di kelas kontrol adalah adalah 46.17, sedangkan, pada posttest skor rata-rata siswa 60.67. Namun, peneliti mendapatkan nilai rata-rata siswa di kelas eksperimen adalah 49.5. Setelah diterapkannya Strategi $P O W+T R E E$, skor rata-rata siswa menjadi 65.50. Dengan demikian, ada peningkatan skor siswa setelah menggunakan strategi. Berdasarkan analisis peneliti dengan menggunakan program SPSS 22.0 pada pengujian Kolmogorov-Smirnov. Berdasarkan hasil pengujian, dapat disimpulkan bahwa sigifikanpada test samadengan standard signifikan 0.05. Oleh karena itu dapat ditarik kesimpulan bahwa terdapat pengaruh yang signifikan antara POW+TREE terhadap hasil belajar siswa.
\end{abstract}

Kata Kunci: menulis, strategi pow+tree

\begin{tabular}{|c|c|c|}
\hline Submitted & Accepted & Published \\
\hline 20 Juli 2019 & 16 Oktober 2019 & 15 November 2019 \\
\hline
\end{tabular}

\begin{tabular}{|l|c|c|c|}
\hline Citation & $:$ & $\begin{array}{c}\text { Dina, H. (2019). Pengaruh Strategi Pow+Tree Terhadap Kemampuan Menulis Paragraf. Jurnal PAJAR (Pendidikan dan } \\
\text { Pengajaran), 3(6), 1384-1395. DOI : http://dx.doi.org/10.33578/pjr.v3i6.7902. }\end{array}$ \\
\hline
\end{tabular}

\section{PENDAHULUAN}

Keterampilan menulis merupakan salah satu keterampilan yang ditekankan pembinaannya, di samping membaca dan berhitung. Keterampilan menulis di sekolah dasar dibedakan atas keterampilan menulis permulaan dan keterampilan menulis lanjut. Akhadijah (1995) mengemukakan bahwa keterampilan menulis sangat kompleks karena menuntut siswa untuk menguasai komponen-komponen didalamnya,misalnya penggunaan ejaan yang benar, pemilihan kosakata yang tepat, penggunaan kalimat efektif, dan penyusunan paragraph yang baik.

Pembelajaran bahasa Indonesia di sekolah dasar meliputi perkembangan bahasa anak, pembelajaran membaca dan menulis permulaan, pembelajaran sastra, pembelajaran terpadu (pendekatan pembelajaran bahasa), 
evaluasi pembelajaran membaca-menulis di sekolah dasar (Nuryamah 2016).

Secara tertulis, orang-orang dapat mengekspresikan pendapat, perasaan, emosi, ide, dan memperkirakan dengan baik. Menurut Nunan (2003), menulis adalah bagaimana mengekspresikan ide dan mengorganisasikannya ke dalam pernyataan dan paragraf. Sementara itu, Boardman dan Frydenberg dalam Afridora (2013), menulis adalah proses berpikir dan pengorganisasian yang berkelanjutan, memikirkan kembali dan mereorganisasi.

Berdasarkan hasil observasi peneliti melalui peninjauan kegiatan proses belajarmengajar di SDN 169 Pekanbaru, penulis menemukan beberapa masalah yang dihadapi siswa dalam keterampilan menulis. Pertama, siswa kesulitan dalam mengembangkan ide yang

\section{KAJIAN TEORETIS}

Menurut Sumarno (2009: 5) menulis berarti mengekspresikan secara tertulis gagasan, ide, pendapat, atau pikiran dan perasaan. Sarana mewujudkan hal itu adalah bahasa. Isi ekspresi melalui bahasa itu akan dimengerti orang lain atau pembaca bila dituangkan dalam bahasa yang teratur, sistematis, sederhana, dan mudah dimengerti.

Dalam pembelajaran bahasa, menulis merupakan salah satu keterampilan yang harus dimiliki oleh siswa. Keterampilan menulis akan menjadi bekal bagi siswa dalam kehidupan seharihari untuk menyampaikan pikiran, perasaan, data, pesan, ide serta gagasan kepada orang lain dalam bentuk keterampilan berbahasa tulis, seperti dalam bentuk surat menyurat antara pengirim dan penerima pesan yang terhalang oleh ruang dan waktu.

Dalam menulis, penulis bebas untuk mengungkapkan ide-ide yang dimilikinya dan dikembangkan sehingga hasil ide yang diungkapkan dapat menjadi bahan bacaan yang berguna bagi pembaca. Dalam mengemukakan ide atau pendapat, penulis tidak akan terlepas dari kalimat yang mendukung ide menjadi sebuah paragraph (Juldianty 2016).

Paragraf merupakan himpunan dari kalimat- kalimat yang bertalian dalam satu dimilikinya. Kedua, rendahnya kemampuan siswa dalam menguasai komponen-kompenen menulis seperti pemilihan kosakata, pengunaan kalimat efektif, dan penyusunan paragraf. Ketiga, mereka sulit untuk menemukan ide yang akan mereka tulis. Dari masalah diatas penulis ingin menerapkan suatu strategi untuk memperbaiki masalah dalam keterampilan menulis siswa melalui penerapan strategi POW+TREE.

$P O W+T R E E$ adalah strategi yang membantu siswa untuk menyampaikan pendapat mereka. Strategi POW+TREE membantu siswa menulis dan mengembangkan ide dengan mudah. Namun, tidak semua siswa dapat menulis jenis teks. Oleh karena itu, di dalam penelitian ini peneliti menerapkan POW+TREE dalam menulis teks paragraf.

rangkaian untuk mernbentuk sebuah gagasan. Sebuah paragraf menjadi jelas setelah ada uraian atau penjelasan yarrg menampilkan pokok-pokok pikiran yang berkaitan dan mendukung gagasan pokok. Tulisan yang baik adalah tulisan yang dapat berkomunikasi dengan pembacanya.

Paragraf adalah sebagai suatu bentuk pengungkapan gagasan yang terjalin dalam rangkaian beberapa kalimat (Mustakim,1994). Menulis paragraf merupakan proses seseorang menuangkan ide atau gagasan yang berupa kumpulan kalimat yang mengandung satu buah kalimat topik dan beberapa kalimat penjelasyang memiliki makna yang berupa informasi yang ditujukan untuk para pembaca.

Dalam menulis paragraf, penulis harus memerhatikan karakteristik dalam menulis paragraf agar tersusun secara sistematis untuk menyampaikan makna kalimat. Gagasan yang dimiliki oleh suatu paragraf hanya memiliki satu pikiran utama atau ide pokok. Ide pokok ini merupakan gagasan utama dari kalimat yang dibuat oleh pengarang. Dengan demikian, kalimat lain yang disertakan dalam paragraf merupakan kalimat pendukung atau kalimat penjelas.

Strategi $P O W+T R E E$ adalah bagian dari SRSD (Self Regulated Strategy Development). Menurut Mason, Harris, dan Graham yang dikutip 
oleh Fahim (2015) bahwa instruksi pada SRSD adalah pendekatan yang kuat untuk mengatasi kekurangan menulis peserta didik yang berkaitan dengan berbagai proses yang terlibat dalam komposisi, tahapan seperti perencanaan, pengeditan, dan pengelolaan proses penulisan.

POW singkatan pick an idea (pilih ide saya), organize your word (atur catatan saya), write and says more(tulis dan katakan lebih banyak). Strategi genre-spesifik untuk menulis pendapat dan mengembangkannya (TREE) dieksploitasi untuk membantu para peserta untuk melakukan langkah kedua dari $P O W$ (mengatur catatan). Atas dasar strategi ini, siswa diajarkan untuk menghasilkan ide atau kalimat yang relevan dengan argumentatif atau persuasif. Para siswa diberitahu bahwa TREE melambangkan empat elemen utama esai persuasif maupun argumentatif. Pertama, topic sentence (topik kalimat), yaitu siswa menulis topik kalimat yang akan dikembangkannya. Kedua, Reasons (alasanalasan), yaitu siswa menulis alasan mereka terhadap topik yang mereka tulis. Ketiga, Explain (penjelasan). Dalam hal ini siswa menjelaskan secara rinci alasan yang mereka ungkapkan, serta Ending (penutup). Siswa memberikan kesimpulan dari topik, alasan, dan penjelasan yang telah ditulis sebelumnya.

\section{METODE PENELITIAN}

Penelitian ini merupakan penelitian quasi eksperimental dengan pendekatan kuantitatif. Quasi eksperimen merupakan penelitian yang bertujuan untuk memperoleh informasi berdasarkan perlakuan (treatment). Pada penelitian ini terdapat dua kelas, satu kelas eksperimen yaitu kelas yang diberi perlakuan (treatment) dengan menggunakan strategi POW+TREE. Kemudian, pada kelas kontrol peneliti tidak menerapkan perlakuan. Oleh karena itu, peneliti dapat membandingkan kemampuan menulis paragraf siswa dengan menggunakan strategi $P O W+T R E E$ dan tidak menggunakan strategi.
Harris, dalam Mason, (2009)menjelaskan bahwa siswa diajarkan untuk menerapkan prosedur langkah demi langka sebagai berikut:

a. $\quad$ P (pilih ide atau topik). Para siswa memilih ide / topik mereka yang dibuat dalam satu paragraf.

b. O (mengatur pikiran Anda dan membuat catatan). Para siswa diminta untuk mengorganisasikan atau mengumpulkan ide yang berhubungan dengan topik yang mereka pilih.

c. W (tulis dan katakan lagi). Para siswa mengembangkan ide yang telah mereka kumpulkan tadi.

d. T (kalimat-topik menyatakan pendapat anda). Para siswa menulis kalimat topik dan menyatakan pendapat mereka.

e. $\mathrm{R}$ (berikan setidaknya tiga alasan untuk mendukung keyakinan mereka). Para siswa menulis alasan mereka untuk mendukung dan meyakinkan pendapat mereka.

f. E (jelaskan alasan Anda dengan lebih rinci). Para siswa menjelaskan alasan mereka secara lebih rinci untuk mendukung pendapat mereka.

g. E (diakhiri dengan pernyataan penutup yang baik). Para siswa membuat paragraf untuk mengakhiri teks dengan pernyataan penutup yang baik.

Dalam penelitian ini, peneliti akan menggunakan dua kelas yaitu kelas Va sebagai kelas eksperimen yang berjumlah 30 orang yang terdiri atas 14 siswa perempuan dan 16 siswa laki-laki. Kelas kontrol penulis memilih kelas $\mathrm{Vb}$ yang berjumlah 30 orang yang terdiri dari 15 siswa laki-laki dan 15 orang siswa perempuan. Dikelas ini penulis menerapkan Strategi $P O W+T R E E$ pada keterampilan menulis paragraf dan untuk mengukur kemampuan menulis siswa, khususnya dalam menulis paragraf serta mengetahui apakah ada pengaruh penerapan strategi POW+TREE terhadap kemampuan menulis siswa kelas V SDN 169 Pekanbaru. 


\section{HASIL DAN PEMBAHASAN}

Tujuan penelitian ini adalah untuk mengetahui pengaruh penerapan strategi POW+TREEterhadap kemampuan kemampuan menulis paragraf siswa kelas V di SDN 169
Pekanbaru. Penelitian ini terdiri dari dua tes yaitu pretest dan posttest dengan jumlah subjek 60 subjek dengan 30 kelas kontrol dan 30 kelas eksperimen.

Tabel 1. Deskripsi Hasil Penelitian

\begin{tabular}{lcccccccc}
\hline Variabel & \multicolumn{3}{c}{$\begin{array}{c}\text { Skor X yang Dimungkinkan } \\
\text { (Hipotetik) }\end{array}$} & \multicolumn{5}{c}{ Skor X yang Diperoleh (Empirik) } \\
& Xmax & Xmin & Mean & SD & Xmax & Xmin & Mean & SD \\
\hline Kontrol & 20 & 5 & 12.5 & 2.5 & 12 & 6 & 9 & 1.74 \\
\hline & & & & & & & & \\
Eksperimen & 20 & 5 & 12.5 & 2.5 & 18 & 11 & 14.13 & 2.06 \\
\hline
\end{tabular}

Berdasarkan tabel di atas, maka dapat dilihat nilai rata-rata empirik skor kemampuan Mengenal bentuk geometrianak meningkat sesudah diberikan eksperimen. Ini menandakan bahwa penggunaan penerapan strategi $P O W+T R E E$ berpengaruh untuk meningkatkan kemampuan anak. Sebelumnya skor rata-rata pada kelas kontroldan rata-rata pada kelas ekperimen 14.13. Ini membuktikan bahwa penggunaan penerapan strategi POW+TREE berpengaruh positif untuk meningkatkan kemampuan menulis paragraf siswa.

Gambaran Umum Kemampuan Menulis Paragraf Siswa Kelas Vdi SDN 169 Pekanbaru Sebelum Perlakuan (Pretest)

\section{1) Kelas Kontrol}

Berdasarkan hasil uji sebelum perlakuan pada kelas kontrol dapat dilihat pada tabel di bawah ini:

Tabel 2. Skor Indikator Pretest KelasKontrol

\begin{tabular}{ccccccc}
\hline No & Indikator & Skor Ideal & $\begin{array}{c}\text { Skor } \\
\text { Faktual }\end{array}$ & Mean & $\%$ & Kategori \\
\hline 1 & Isi & 120 & 33 & 1.10 & $27.50 \%$ & Rendah \\
2 & Organisasi & 120 & 34 & 1.13 & $28.33 \%$ & Rendah \\
3 & Tata Bahasa & 120 & 35 & 1.17 & $29.17 \%$ & Rendah \\
4 & Kosa Kata & 120 & 43 & 1.43 & $35.83 \%$ & Rendah \\
5 & Ejaan & 120 & 52 & 1.73 & $43.33 \%$ & Rendah \\
\hline \multirow{2}{*}{ Jumlah } & & 600 & 197 & 6.56667 & $32.83 \%$ & Rendah \\
\hline
\end{tabular}

Berdasarkan tabel di atas diketahui pada indikator 1 diperoleh skor 33 atau $27.50 \%$ dari yang diharapkan, pada indikator 2 diperoleh skor 34 atau $28.33 \%$ dari yang diharapkan, dan pada indikator 3 diperoleh skor 35 atau $29.17 \%$ dari yang diharapkan. Pada indikator 4 diperoleh skor
43 atau $35.83 \%$ dari yang diharapkan, pada indikator 5 diperoleh skor 52 atau $43.33 \%$ dari yang diharapkan. Indikator dengan nilai tertinggi adalah ejaan dengan skor 52 atau $43.33 \%$ dari yang diharapkan, dan yang terendah adalah indikator isi dengan skor 33 atau $27.50 \%$ dari 
yang diharapkan.

Untuk mengetahui gambaran kemampuan menulis paragraf siswa sebelum diberikan perlakuan menggunakan penerapan strategi POW+TREE maka dapat dilihat pada tabel berikut:

Tabel 3. Kategori Skor Subjek Penelitian pada Pretest Kelas Kontrol

\begin{tabular}{ccccc}
\hline No & Kategori & Skor & F & \% \\
\hline 1 & Sangat Tinggi & $76 \%-100 \%$ & 0 & $0.00 \%$ \\
2 & Tinggi & $51 \%-75 \%$ & 0 & $0.00 \%$ \\
3 & Rendah & $26 \%-50 \%$ & 22 & $73.33 \%$ \\
4 & Sangat Rendah & $1 \%-25 \%$ & 8 & $26.67 \%$ \\
\hline & Jumlah & & $\mathbf{3 0}$ & $\mathbf{1 0 0 . 0 0 \%}$ \\
\hline
\end{tabular}

Berdasarkan tabel di atas maka diketahui bahwa kemampuan menulis paragraf pada siswa sebelum penggunaan penerapan strategi $P O W+T R E E$ atau $0 \%$ siswa berada pada kategori sangat tinggi, 0 siswa atau $0 \%$ berada pada kategori tinggi, 22 siswa atau $73.33 \%$ berada pada kategori rendah, dan 8 atau $26.67 \%$ siswa berada pada kategori sangat rendah. Melihat rata-rata persentase yang dihasilkan siswa yaitu $32.83 \%$ maka dapat disimpulkan kemampuan menulis paragraf siswa kelas V SDN 169 Pekanbaru berada pada kategori rendah.

\section{2) Kelas Eksperimen}

Berdasarkan hasil uji sebelum perlakuan pada kelas eksperimen dapat dilihat pada tabel di bawah ini:

Tabel 4. Skor Indikator Pretest Kelas Eksperimen

\begin{tabular}{ccccccc}
\hline No & Indikator & $\begin{array}{c}\text { Skor } \\
\text { Ideal }\end{array}$ & $\begin{array}{c}\text { Skor } \\
\text { Faktual }\end{array}$ & Mean & \% & Kategori \\
\hline 1 & Isi & 120 & 48 & 1.60 & $40.00 \%$ & Rendah \\
2 & Organisasi & 120 & 48 & 1.60 & $40.00 \%$ & Rendah \\
3 & Tata Bahasa & 120 & 46 & 1.53 & $38.33 \%$ & Rendah \\
4 & Kosa Kata & 120 & 56 & 1.87 & $46.67 \%$ & Rendah \\
5 & Ejaan & 120 & 60 & 2.00 & $50.00 \%$ & Rendah \\
\hline \multirow{2}{*}{ Jumlah } & & $\mathbf{6 0 0}$ & $\mathbf{2 5 8}$ & $\mathbf{8 . 6}$ & $\mathbf{4 3 . 0 0 \%}$ & Rendah \\
\hline
\end{tabular}

Berdasarkan tabel di atas diketahui pada indikator 1 diperoleh skor 48 atau 40\% dari yang diharapkan, pada indikator 2 diperoleh skor 48 atau $40 \%$ dari yang diharapkan, dan pada indikator 3 diperoleh skor 46 atau $38.33 \%$ dari yang diharapkan. Pada indikator 4 diperoleh skor
56 atau $46.67 \%$ dari yang diharapkan, pada indikator 5 diperoleh skor 60 atau 50\% dari yang diharapkan. Indikator dengan nilai tertinggi adalah ejaan dengan skor 60 atau 50\% dari yang diharapkan, dan yang terendah adalah indikator tata bahasa dengan skor 46 atau $38.33 \%$ dari yang 
diharapkan.

Untuk mengetahui gambaran kemampuan menulis paragraf siswa sebelum diberikan perlakuan menggunakan penerapan strategi $P O W+$ TREE maka dapat dilihat pada tabel berikut:

Tabel 5. Kategori Skor Subjek Penelitianpada Pretest Kelas Eksperimen

\begin{tabular}{ccccc} 
No & Kategori & Skor & F & \% \\
\hline 1 & Sangat Tinggi & $76 \%-100 \%$ & 0 & $0.00 \%$ \\
2 & Tinggi & $51 \%-75 \%$ & 5 & $16.67 \%$ \\
3 & Rendah & $26 \%-50 \%$ & 21 & $70.00 \%$ \\
4 & Sangat Rendah & $1 \%-25 \%$ & 4 & $13.33 \%$ \\
\hline & Jumlah & & $\mathbf{3 0}$ & $\mathbf{1 0 0 . 0 0 \%}$ \\
\hline
\end{tabular}

Berdasarkan tabel di atas maka dapat diketahui kemampuan menulis paragraf pada siswa sebelum penggunaan penerapan strategi POW+TREE atau 0\% siswa berada pada kategori sangat tinggi, 5 siswa atau $16.67 \%$ berada pada kategori tinggi, 21 siswa atau $70 \%$ berada pada kategori rendah, dan 4 atau $13.33 \%$ siswa berada pada kategori sangat rendah. Melihat rata-rata persentase yang dihasilkan siswa yaitu $43.00 \%$ maka dapat disimpulkan kemampuan menulis paragraf siswa kelas V SDN 169 Pekanbaru berada pada kategori rendah.

Gambaran UmumKemampuan Menulis Paragraf Siswa Kelas V Di SDN 169 Pekanbaru Sesudah Diberikan Perlakuan (Posttest)

1) Kelas Kontrol

Setelah penerapan strategi POW+TREE pada kelas eksperimen dilakukan kemudian kedua kelas dilakukan posttes. Berikut hasil posttest kela kontrol.

Tabel 6. Skor Indikator Posttest Kelas Kontrol

\begin{tabular}{ccccccc}
\hline No & Indikator & $\begin{array}{c}\text { Skor } \\
\text { Ideal }\end{array}$ & $\begin{array}{c}\text { Skor } \\
\text { Faktual }\end{array}$ & Mean & $\%$ & Kategori \\
\hline 1 & Isi & 120 & 50 & 1.67 & $41.67 \%$ & Rendah \\
2 & Organisasi & 120 & 51 & 1.70 & $42.50 \%$ & Rendah \\
3 & Tata Bahasa & 120 & 45 & 1.50 & $37.50 \%$ & Rendah \\
4 & Kosa Kata & 120 & 57 & 1.90 & $47.50 \%$ & Rendah \\
5 & Ejaan & 120 & 67 & 2.23 & $55.83 \%$ & Tinggi \\
\hline Jumlah & & 600 & 270 & 9 & $45.00 \%$ & Rendah \\
\hline
\end{tabular}

Berdasarkan tabel di atas diketahui pada indikator 1 diperoleh skor 50 atau $41.67 \%$ dari yang diharapkan, pada indikator 2 diperoleh skor 51 atau $42.50 \%$ dari yang diharapkan, dan pada indikator 3 diperoleh skor 45 atau $37.50 \%$ dari yang diharapkan, pada indikator 4 diperoleh skor 57 atau $47.50 \%$ dari yang diharapkan, pada indikator 5 diperoleh skor 67 atau $55.83 \%$ dari yang diharapkan. Skor tertinggi pada indikator ejaan dengan skor 67 atau $55.83 \%$ dari yang 
diharapkan, dan indikator terendah pada indikator tata bahasa dengan skor 45 atau $37.50 \%$ dari yang diharapkan.

Untuk mengetahui gambaran kemampuan menulis paragraf pada siswa setelah diberikan perlakuan penerapan strategi $P O W+T R E E$ maka dapat dilihat pada tabel berikiut:

Tabel 7. Kategori Skor Subjek Penelitianpada Posttest Kelas Kontrol

\begin{tabular}{ccccc}
\hline No & Kategori & Skor & F & \% \\
\hline 1 & Sangat Tinggi & $76 \%-100 \%$ & 0 & $0.00 \%$ \\
2 & Tinggi & $51 \%-75 \%$ & 8 & $26.67 \%$ \\
3 & Rendah & $26 \%-50 \%$ & 22 & $73.33 \%$ \\
4 & Sangat Rendah & $1 \%-25 \%$ & 0 & $0.00 \%$ \\
\hline & Jumlah & & $\mathbf{3 0}$ & $\mathbf{1 0 0 . 0 0 \%}$ \\
\hline
\end{tabular}

Berdasarkan tabel di atas maka diketahui bahwa kemampuan kemampuan menulis paragraf siswapada kelas kontrol diperoleh 0 atau $0 \%$ siswa berada pada kategori sangat tinggi, 8 atau $26.67 \%$ siswa berada pada kategori tinggi, 22 atau $73.33 \%$ siswa berada pada kategori rendah, dan 0 atau $0 \%$ anak berada pada kategori sangat Rendah. Melihat rata-rata persentase yang dihasilkan oleh kelas kontrol sebesar 45\% maka dapat disimpulkan kemampuan menulis paragraf kelas kontrol pada kategori rendah.

2) Kelas Eksperimen

Setelah penerapan strategi POW+TREE pada kelas eksperimen dilakukan kemudian kedua kelas dilakukan posttes.Berikut hasil posttest kelas eksperimen.

Tabel 8. Skor Indikator Posttest Kelas Eksperimen

\begin{tabular}{ccccccc}
\hline No & Indikator & $\begin{array}{c}\text { Skor } \\
\text { Ideal }\end{array}$ & $\begin{array}{c}\text { Skor } \\
\text { Faktual }\end{array}$ & Mean & \% & Kategori \\
\hline 1 & Isi & 120 & 80 & 2.67 & $66.67 \%$ & Tinggi \\
2 & Organisasi & 120 & 77 & 2.57 & $64.17 \%$ & Tinggi \\
3 & Tata Bahasa & 120 & 76 & 2.53 & $63.33 \%$ & Tinggi \\
4 & Kosa Kata & 120 & 91 & 3.03 & $75.83 \%$ & Tinggi \\
& Ejaan & 120 & 100 & 3.33 & $83.33 \%$ & Tinggi \\
\hline 5 & & $\mathbf{6 0 0}$ & $\mathbf{4 2 4}$ & $\mathbf{1 4 . 1 3}$ & $\mathbf{7 0 . 6 7 \%}$ & Tinggi \\
\hline
\end{tabular}

Berdasarkan tabel di atas diketahui pada indikator 1 diperoleh skor 80 atau $66.67 \%$ dari yang diharapkan, pada indikator 2 diperoleh skor 77 atau $64.17 \%$ dari yang diharapkan, dan pada indikator 3 diperoleh skor 76 atau $63.33 \%$ dari yang diharapkan, pada indikator 4 diperoleh skor 91 atau $75.83 \%$ dari yang diharapkan, pada indikator 5 diperoleh skor 100 atau $83.33 \%$ dari 
yang diharapkan. Skor tertinggi pada indikator ejaan dengan skor 100 atau $83.33 \%$ dari yang diharapkan, dan indikator terendah pada indikator tata bahasa dengan skor 76 atau $63.33 \%$ dari yang diharapkan.
Untuk mengetahui gambaran kemampuan menulis paragraf pada siswa setelah diberikan perlakuan penerapan strategi $P O W+T R E E$ maka dapat dilihat pada tabel berikiut:

Tabel 9. Kategori Skor Subjek Penelitian pada Posttest Kelas Eksperimen

\begin{tabular}{ccccc} 
No & Kategori & Skor & F & \% \\
\hline 1 & Sangat Tinggi & $76 \%-100 \%$ & 7 & $23,33 \%$ \\
2 & Tinggi & $51 \%-75 \%$ & 23 & $76.67 \%$ \\
3 & Rendah & $26 \%-50 \%$ & 0 & $0.00 \%$ \\
4 & Sangat Rendah & $1 \%-25 \%$ & 0 & $0.00 \%$ \\
\hline & Jumlah & & $\mathbf{3 0}$ & $\mathbf{1 0 0 . 0 0 \%}$ \\
\hline
\end{tabular}

Berdasarkan tabel di atas maka dapat diketahui bahwa kemampuan kemampuan menulis paragraf siswa pada kelas ekperimen diperoleh 7 atau $23.33 \%$ siswa berada pada kategori sangat tinggi, 23 atau $76.67 \%$ siswa berada pada kategori tinggi, 0 atau $0 \%$ siswa berada pada kategori rendah, dan 0 atau $0 \%$ anak berada pada kategori sangat Rendah. Berdasarakan rata-rata persentase yang dihasilkan kelas eksperimen yaitu $71 \%$ maka dapat disimpulkan kemampuan menulis paragraf siswa kelas ekperimen berada pada kategori tinggi.

\section{Perbandingan Data Kelas Kontrol dan Kelas} Eksperimen

1) Kelas Kontrol

Adapun hasil pretest dan posttest dapat dilihat pada tabel dibawah ini:

Tabel 10. Rekapitulasi Kemampuan Menulis Paragraf Sebelum dan Sesudah pada Kelas Kontrol

\begin{tabular}{ccccccc}
\hline No & Kategori & Skor & F & Sebelum & F & Sesudah \\
\hline 1 & Sangat Tinggi & $76 \%-100 \%$ & 0 & $0.00 \%$ & 0 & $0.00 \%$ \\
2 & Tinggi & $51 \%-75 \%$ & 0 & $0.00 \%$ & 8 & $26.67 \%$ \\
3 & Rendah & $26 \%-50 \%$ & 22 & $73.33 \%$ & 22 & $73.33 \%$ \\
4 & Sangat Rendah & $1 \%-25 \%$ & 8 & $26.67 \%$ & 0 & $0.00 \%$ \\
\hline & Jumlah & & 30 & $100.00 \%$ & 30 & $100.00 \%$ \\
\hline
\end{tabular}

Tabel di atas menunjukkan kondisi subjek kelas kontrol terlihat perbedaan yang tidak terlalu signifikan antara pretest dan posttets.
2) Kelas Eksperimen

Adapun hasil pretest dan posttest dapat dilihat pada tabel dibawah ini: 
Tabel 11. Rekapitulasi Kemampuan Menulis Paragraf Sebelum dan Sesudah pada Kelas Eksperimen

\begin{tabular}{ccccccc}
\hline No & Kategori & Skor & F & $\%$ & F & $\%$ \\
\hline 1 & Sangat Tinggi & $76 \%-100 \%$ & 0 & $0.00 \%$ & 7 & $23.33 \%$ \\
2 & Tinggi & $51 \%-75 \%$ & 5 & $16.67 \%$ & 23 & $76.67 \%$ \\
3 & Rendah & $26 \%-50 \%$ & 21 & $70.00 \%$ & 0 & $0.00 \%$ \\
4 & Sangat Rendah & $1 \%-25 \%$ & 4 & $13.33 \%$ & 0 & $0.00 \%$ \\
\hline & Jumlah & & 30 & $100.00 \%$ & 30 & $100.00 \%$ \\
\hline
\end{tabular}

Tabel di atas menunjukkan kondisi subjek kelas eskperimen setelah perlakuan strategi $P O W+T R E E$ terlihat perbedaan yang signifikan antara pretest dan posttets.
3) Posttest Kelas Kontrol dan Eksperimen

Adapun hasil posttest dapat dilihat pada tabel dibawah ini:

Tabel 12. Rekapitulasi Kemampuan Menulis Paragraf Sebelum dan Sesudah pada Kelas Ekperimen dan Kelas Kontrol

\begin{tabular}{ccccccc}
\hline No & Kategori & Skor & F & Kontrol & F & Eksperimen \\
\hline 1 & Sangat Tinggi & $76 \%-100 \%$ & 0 & $0.00 \%$ & 7 & $23.33 \%$ \\
2 & Tinggi & $51 \%-75 \%$ & 8 & $26.67 \%$ & 23 & $76.67 \%$ \\
3 & Rendah & $26 \%-50 \%$ & 22 & $73.33 \%$ & 0 & $0.00 \%$ \\
4 & Sangat Rendah & $1 \%-25 \%$ & 0 & $0.00 \%$ & 0 & $0.00 \%$ \\
\hline & Jumlah & & 30 & $100.00 \%$ & 30 & $100.00 \%$ \\
\hline
\end{tabular}

Tabel di atas menunjukkan kondisi subjek kelas kontrol dan kelas eskperimen setelah

\section{PEMBAHASAN}

Pembahasan hasil penelitian ini dilakukan melalui hasil analisis perbandingan pada penelitian dengan jenis penelitian eksperimen terhadap variabel bebas yaitu penerapan strategi POW+TREE (X) dan variabel terikat yaitu kemampuan menulis paragraf siswa (Y). Untuk melihat perubahan sebelum dan sesudah dilakukan perlakuan (treatment) terhadap sampel. Setelah melakukan hasil perbedaan nilai sebelum (pretest) dan sesudah (posttest) dari perlakuan, langkah selanjutnya yaitu melihat kemampuan mengenal bentuk geometri anak dengan perlakuan yang telah diberikan kepada anak.

Pada kelas kontrol setelah dilakukan pretest diketahui pada indikator isi diperoleh skor 33 atau $27.50 \%$ dari yang diharapkan.Artinya kemampuan anak untuk menuangkan Isi karangan dapat berupa ide, pengalaman, fakta, atau perlakuan strategi $P O W+T R E E$ terlihat perbedaan yang signifikan antara kedua kelas tersebut.

informasi-informasi yang diperoleh melalui bacaan masih berada pada taraf yang rendah.Pada indikator bentuk karangan diperoleh skor 34 atau $28.33 \%$ dari yang diharapkan. Artinya anak belum mampu atau masih tergolong rendah dalam menentukan tulisan yang akan dibuatnya. Apakah berbentuk novel, cerpen, dongeng, atau karya lain. Pada indikator tata bahasa diperoleh skor 35 atau $29.17 \%$ dari yang diharapkan. Artinya kemampuan siswa dalam menata bahasa pada tulisannya masih tergolong rendah. Kemampuan dalam menanata bahasa yang dimaksud adalah menggabungkan kata-kata dan lain sebagainya.

Pada indikator gaya bahasa diperoleh skor 43 atau $35.83 \%$ dari yang diharapkan. Artinya kemampuan anak dalam memilih diksi pada tulisannya tergolong masih rendah. Pada indikator penerapan ejaan diperoleh skor 52 atau 
43.33\% dari yang diharapkan. Artinya kemampuan siswa dalam membuat ejaan masih tergolong rendah. Indikator dengan nilai tertinggi adalah ejaan dengan skor 52 atau $43.33 \%$ dari yang diharapkan, dan yang terendah adalah indikator isi dengan skor 33 atau $27.50 \%$ dari yang diharapkan.

Untuk melihat kondisi subjek pada kelas kontrol saat pretest, subjek digolongkan ke dalam empat kategori: 0 atau 0\% siswa berada pada kategori sangat tinggi, 0 siswa atau $0 \%$ berada pada kategori tinggi, 22 siswa atau $73.33 \%$ berada pada kategori rendah, dan 8 atau $26.67 \%$ siswa berada pada kategori sangat rendah. Melihat rata-rata persentase yang dihasilkan siswa yaitu $32.83 \%$ maka dapat disimpulkan kemampuan menulis paragraf siswa kelas V SDN 169 Pekanbaru berada pada kategori rendah.

Kemudian pada posttest diketahui pada indikatorisi diperoleh skor 50 atau $41.67 \%$ dari yang diharapkan. Artinya terdapat peningkatan dari skor pretest dalam menuangkan berbagai hal ke dalam tulisannya. Akan tetapi peningkatan yang terjadi belum signifikan sehingga masih berada pada kategori rendah. Pada indikator bentuk karangan diperoleh skor 51 atau $42.50 \%$ dari yang diharapkan. Ini juga menunjukkan peningkatan akan tetapi belum signifikan sehingga indikator ini masih pada kategori rendah. Pada indikator tata bahasa diperoleh skor 45 atau $37.50 \%$ dari yang diharapkan, pada saat posttest tata bahasa juga belum menunjukkan perkemabangan yang signifikan pada siswa dikelas kontrol. Pada indikator Gaya bahasa diperoleh skor 57 atau $47.50 \%$ dari yang diharapkan artinya kemampuan siswa dalam menggunakan gaya bahasa pada tulisannya setelah dilakukan posttest masih pada kategori rendah. Pada indikatorejaan diperoleh skor 67 atau $55.83 \%$ dari yang diharpkan.Artinya kemampuan siswa pada ejaan sudah tergolong tinggi hal ini terlihat dari peningkatan yang terjadi.

Untuk melihat kondisi subjek pada kelas kontrol saat pretest, subjek digolongkan ke dalam empat kategori: 0 atau 0\% siswa berada pada kategori sangat tinggi, 8 atau $26.67 \%$ siswa berada pada kategori tinggi, 22 atau $73.33 \%$ siswa berada pada kategori rendah, dan 0 atau $0 \%$ anak berada pada kategori sangat Rendah. Melihat rata-rata persentase yang dihasilkan oleh kelas kontrol sebesar $45 \%$ maka dapat disimpulkan kemampuan menulis paragraf kelas kontrol pada kategori rendah.

Pada kelas eksperimen juga dilakukan hal yang sama dengan kelas kontrol yaitu pretest dan posttest. Yang membedakan keduanya adalah pada kelas eksperimen diterapkan strategi $P O W+T R E E$ sebagai alat untuk meningkatkan kemampuan menulis paragraf siswa kelas $\mathrm{V}$ di SDN 169 Pekanbaru. Pada pretest kelas eksperimen diperoleh pada indikator isi diperoleh skor 48 atau $40 \%$ dari yang diharapkan, pada indikator bentuk karangan diperoleh skor 48 atau $40 \%$ dari yang diharapkan, dan pada indikator tata bahasa diperoleh skor 46 atau $38.33 \%$ dari yang diharapkan. Pada indikator gaya bahasa diperoleh skor 56 atau $46.67 \%$ dari yang diharapkan, pada indikator penggunaan ejaan diperoleh skor 60 atau 50\% dari yang diharapkan. Indikator dengan nilai tertinggi adalah ejaan dengan skor 60 atau 50\% dari yang diharapkan, dan yang terendah adalah indikator tata bahasa dengan skor 46 atau $38.33 \%$ dari yang diharapkan. Pada keseluruhan indikator menunjukkan tingkat atau kategori rendah.

Setelah dilakukan pretest kemudian startegi POW+TREE kemudian diterapkan kepada siswa kelas $\mathrm{V}$. setelah rancangan treatment selesai dilaksanakan kemudian peneliti melakukan posttest. Pada posttest kelas eksperimen diperoleh hasil pada indikator isi diperoleh skor 80 atau $66.67 \%$ dari yang diharapkan, pada indikator bentuk karangan diperoleh skor 77 atau $64.17 \%$ dari yang diharapkan, dan pada indikator tata bahasa diperoleh skor 76 atau $63.33 \%$ dari yang diharapkan, pada indikator gaya bahasa diperoleh skor 91 atau $75.83 \%$ dari yang diharapkan, pada indikator bentuk ejaan diperoleh skor 100 atau $83.33 \%$ dari yang diharpkan. Skor tertinggi pada indikator ejaan dengan skor 100 atau $83.33 \%$ dari yang diharapkan, dan indikator terendah pada indikator tata bahasa dengan skor 76 atau $63.33 \%$ dari yang diharapkan. Keseluruhan indikator menunjukkan perkembangan yang sangat signifikan dari pretest dimana seluruh indikator berada pada kategori tinggi. 
Untuk mengetahui gambaran kemampuan menulis paragraf pada siswa setelah diberikan perlakuan penerapan strategi $P O W+T R E E$ maka siswa digolongkan kedalam empat kategori: 7 atau $23.33 \%$ siswa berada pada kategori sangat tinggi, 23 atau $76.67 \%$ siswa berada pada kategori tinggi, 0 atau $0 \%$ siswa berada pada kategori rendah, dan 0 atau $0 \%$ anak berada pada kategori sangat rendah. Berdasarakan rata-rata persentase yang dihasilkan kelas eksperimen yaitu $71 \%$ maka dapat disimpulkan kemampuan menulis paragraf siswa kelas ekperimen berada pada kategori tinggi.

Setelah hasil penelitian sudah dipaparkan kemudian peneliti akan melakukan uji prasyarat berupa uji linearitas, uji homogenitas, dan uji normalitas sebelum melakukan uji hipotesis

\section{SIMPULAN DAN REKOMENDASI}

Berdasarkan hasil penelitian yang dilakukan di SDN 169 Kota Pekanbaru, Maka dapat disimpulkan bahawa ada pengaruh yang signifikan dari strategi POW+TREE terhadap kemampuan menulis paragraf siswa kelas $\mathrm{V}$ di SDN 169 Pekanbaru hal ini dapat diihat dari analasis data yang telah dilakukan. Berdasarkan analisis data pada bab sebelumnya dapat dijelaskan kesimpulan dari penelitian ini yaitu, memampuan menulis paragraf siswakelas $\mathrm{V}$ di SDN 169 Kota Pekanbaru pada kelas control tergolong rendah yakni setelah dilakukan posttest diperoleh hasil $45 \%$ dari yang diharapkan, kemudian terdapat pengaruh yang signifikan strategi POW+TREE terhadap kemampuan menulis paragraf siswa kelas V di SDN 169 Pekanbaru, dengan thitung $=10.412$ dengan signifikasi $=0,000$. Berdasarkan uji N-Gen diperoleh $48.54 \%$ strategi POW+TREE memberikan pengaruh dalam kategori sedang

\section{DAFTAR PUSTAKA}

Afridona, L. (2003). Teaching Writing Exposition Text by Combining Hamburger Strategy and Quik Write Strategy for Senior High School Student. National Journal. Retrived from dengan menggunakan independent $t$ test.

Selanjutnya peneliti melakukan uji perbandingan kelas controldan kelas eksperimen dengan menggunakan uji independent t test. Uji signifikan perbedaan ini dengan $t$ stastitik diperoleh $\mathrm{t}_{\text {hitung }} 10.412$ karena nilai (Sig.2-tailed) $=0.00$. Karena nilai Sig. $<0.05$,terdapat pengaruh penerapan strategi POW+TREE terhadap kemampuan kemampaun menulis paragraf siswa kelas V di SDN 169 Pekanbaru. Untuk melihat seberapa besar pengaruh penerapan strategi POW+TREE terhadap kemampuan kemampaun menulis paragraf siswa kelas Vdi SDN 169 Pekanbaru dilakukan uji N-Gen dan diperoleh hasil $48.54 \%$ dan sisanya $51.46 \%$ dipengaruhi oleh faktor lain. Misalnya kondisi subjek saat dilakukan observasi.

terhadap kemampuan menulis paragraf siswa kelas V di SDN 169 Pekanbaru.

Berhubungan dengan hasil penelitian ini, peneliti ingin memberikan saran yang berharga kepada mereka yang menunjukkan perhatian yang tinggi untuk mengajar bahasa Indonesia terutama dalam kemampuan menulis ialah kepada guru bahasa Indonesia, yakni harus kreatif dan inovatif dalam mengajar siswa. Kemudian, harus menerapkan teknik, metode, atau strategi dalam proses belajar mengajar. Hal itu dapat membuat siswa mudah mencapai tujuan belajar. Selanjutnya, untuk peneliti berikutnyayang akan melakukan penelitian, lebih baik bagi peneliti berikutnya untuk menggunakan teknik, strategi, atau metode yang tepat dalam melakukan penelitian. Jika peneliti menggunakan strategi yang tepat untuk mengajarkan keterampilan berbahasa, hal itu dapat membuat siswa mudah untuk mencapai tujuan pembelajaran.

http://download.portalgaruda.org/article.ph $\mathrm{p}$

Akhadiah, S. (1995). Pembinaan Kemampuan Menulis Bahasa Indonesia. Jakarta: Balai Pustaka. 
Fahim, M. (2015). Applying self-regulated strategy development model of intruction to teach writing skill: Effects on writing performance and writing motivation of EFL learners. 4 (2). International Journal of Resarch Study in Education. ISSN 22437703. Retrived from. http://www.consortiacademia.org

Juldianty. (2016). Peningkatan Keterampilan Menulis melalui Penggunaan Media Gambar Seri Siswa Keas III. Jurnal Nasional. 7 (2). 100- 109.

Mason, H. L, et al. (2009). Developing Quick Writing Skills of Middle School Students With Dissabilities. Journal Special Education. International Journal. Retrived. from htttp://www researchgate.net

Mason, H. L, et al. (2013). Improving Quick Writing Performance of Middle-School Struggling Learners. International Journal. Contemporary Educational Psychology 38. ISSN 27599-3500. Retrived from. http://www.sciencedirect.com

Mustakim. (1994). Membina Kemampuan Berbahasa. Jakarta : PT Gramedia Pustaka Utama.

Nunan, D. (2003). Practical English Language Teaching. New York : Mc Graw- Hill Companies, Inc.

Nuryamah, I. (2016). Upaya Meningkatkan Keterampilan Menulis Permulaan dalam Melengkapi Cerita Rumpang Menggunakan Media Gambar dan Papan Bergaris. Nasional Jurnal Pena Ilmiah, 1 (1). 23- 28.

Siregar, S. (2013). Metode Penelitian Kuantitatif. Jakarta: Prenadamedia Group.

Sumarmo, dkk. (2009). Pembelajaran Menulis. Jakarta: Department Pendidikan Nasional.

Yogyantoro. (2016). Peningkatan Keterampilan Menulis Karangan Deskripsi Menggunakan Media Diorama Siswa Kelas IV. Jurnal Pendidikan Guru Sekolah Dasar, 1(1). 9098. 